\title{
State Fragility and Organized Crime
}

\author{
Rabi Raj Thapa \\ Additional Inspector General of APF, Nepal (Retd) \\ Academic Program Coordinator, APF Command and Staff College \\ Email: thapa.rabiraj@gmail.com
}

\begin{abstract}
s
There are always probabilities of strong relationships between transnational organized crime group, the government, semi-government agencies and irregular formations. Because, at the fundamental level, motivations and aspirations of all these agencies and groups may be similar, i.e. making as much money or profit as quickly as possible; whether in a semi-legitimate or illegitimate means and ways. For this, they will be ready to use any modus operandi; the end result and harm they cause to the nation and society will be the same. Therefore, more often it is also very difficult to distinguish them one from another. In this regard, they all can be termed "the silent partners" of the legitimate government agencies, semi-government corporations and the organized crime groups (OCGs) and wherever they belong: they converge at a single platform, i.e. the Organized Crime. Therefore, the silent partners of the Organized Crime Group can be any of these: a private party or person, a government officer or his office, a semi-government official or a group of people belonging to these organizations. There may be another similarity among these too; ...i.e. they all do their utmost to avoid their appearance in public or willingly acknowledged their involvement in any form and deeds on such cooperative undertaking. There are many ways such organized syndicates apply their methods that may be soft, peaceful to even gruesomely violent means to get access to state power, money or government resources. In this regard, they may apply all types of legitimate and illegitimate means, to name the few, such as protection rackets, and capture public resources, seize of property and land forcibly in an illegitimate way, and eventually entry into the licit private sector by money laundering and other means.
\end{abstract}

Key Words: Organized crime, organized crime groups (OCGs), transnational criminal groups, corruption, and fragile-state

\section{Introduction}

Regarding contemporary scenario of Nepal, Felbab-Brown writes, "Rather than focusing on adopting lasting governance procedures to advance the national interest and well-being of all Nepalese, political competition in Nepal has centered on narrow, parochial competition between a variety of powerbrokers seeking to leverage their control of specific communities, voting blocks, resources and patronage networks" (Felbab-Brown, 2013). She has interpreted Nepal as a deeply improvised but resource-rich country (that) can ill afford further political paralysis and Nepal's politics over the past few years characterized as 'protest without prescription' (Felbab-Brown, 2013, pp. 56-57).

For any external observer like Felbab Brown, the contemporary Nepal looks like "... a process leading to severe degradation in administrative capacity, a pervasive lack of merit-based personnel system, and poor service delivery (Felbab-Brown, 2013, p. 57). In the past two decades, especially during the armed conflict of 1996-2006, many parts of Nepal were controlled by irregular armed groups, political parties, local armed groups, and criminal gangs but less by the state government. Despite all these, organized criminal acts, encompassing both politically-motivated and economically-driven crimes, are still in its initial developmental stages (Felbab-Brown, 2013, p. 57). Unfortunately, in this post-conflict scenario of Nepal, the nexus between crime and political parties seems to be getting deeper and stronger, and getting immune and collaborate with criminal groups for political purposes, including demonstrating street power, raising money for the party, and securing contracts for clients and so many government undertakings. Hence, contemporary criminal landscape of Nepal is still primitive state in organized crime formations. The criminal groups tend to be mostly small, territorially limited organizations, and their operation is not highly complex (Felbab-Brown, 2013, p. 57).

Many commitments of ' zero-tolerance on crime and criminals' have been repeatedly emphasized by many successive government of Nepal since the political changes of 1990 till date; and especially after the second people's revolt 2006. In this regard, Nepal seems to becoming a fertile ground for the Organized Groups (OCGs) and their silent partners in these days. For this, it would be pertinent to understand the appropriate meaning of organized crime. Gus Taylor (1962) defines organized crime as, "Organized Crime (Racketeering) crops up mostly in the new areas of new business enterprise which 
have not yet been reduced to order or become subject to tradition, and where economic change moves more rapidly" and he further reiterates, "the serious threat of violence and crime appear at the times of greatest social change, involving rapid migration of population, the shifting of industries, the contact and clash of subcultures, the improvement of living standard, and the opening of new perspectives for which people are not yet prepared". At the present context, Nepal seems to be falling more and more on the trap of criminals of Organized Crime Groups (OCGs) day by day.

In any organized crime, the 'big fishes' have always proven to be stronger and smarter. Like any weak and fragile countries of Asia, Africa and South America; criminal groups in Nepal are increasingly gaining power and money; spreading their tentacles wider and wider, faster and gaining more ferocity. At the present juncture, people are apprehensive of a strong possibility of the development of strong nexus and partnership between government, regular/ irregular groups and the OCGs to work as silent partners in legitimate business in an illegitimate way which may harm the country and the people in the long run.

After the promulgation of the Federal Constitution 2015, Nepal is in a process of restructuring its whole system and processes. Therefore, it is but natural to be at a fragile state, more vulnerable to all types of challenges, including social disorder, dissention and organized trans-national crime. In such a precarious and vulnerable situation, organized and transnational crime may become stronger and institutionalized, because they are always on a move to find a platform for their criminal operation as a safe heaven, a transit point or even a criminal base that may threaten and stabilize the whole South Asian region.

Recently, there is a growing trend of writing biographies and books by many prominent social elites of various disciplines whether it is the chief justice of the Supreme Court, the Army Chiefs, Inspector General of Police or the journalist, business tycoons and Helicopter pilot. Their books have helped Nepalese people to understand the depth of our economic social and political environment where illegal, unethical partnership between the government stakeholders, power brokers, manipulating private parties with various national and international organized crime groups are working together.

In this regard, Former Chief Justice Sushila Karki has mentioned some big cases dealt by her in her book, Nyaya [Justice] (Karki, 2018, pp. 217-299). In her book, she has clearly indicated the public, government officials and general public working like the silent partners who engage in corruption, illegal and illegitimate transaction amounting to crime in one way or another. Onee of the former IGP of Nepal Police, Achyut Krishna Kharel elaborates some of the cases of the criminalization of politics and politicization of crime by politicians, ministers and high level government officials in his biography. He has boldly written the involvement of government ministers and their involvement in gold smuggling through international airport of Nepal (Kharel, 2018). A prominent journalist of Nepal, Sudheer Sharma has depicted Nepal as a Laboratory of foreign agents, organized crime group, commission agents and various nefarious activities from Nepal as a platform. Similarly, Sudheer Adhikari has written about the organized crime nexus in Nepal since decades that has initiated the crime and violence amounting to murder, assassination and terror in Nepal orchestrated by the notorious organized crime boss Dawood Ibrahim since two decades. That was one of the bloodiest international crime amounting to Indian counterfeit currency and assassinations of the parliamentarian Mirja Dil Sad Begh, Media Tycoon Jamim Shah and Faijan Ahmad as a result of their turf war within Nepalese territory (Adhikari, 2012).

As a matter of fact, post conflict Nepal after 1996 till date can be taken as a best harvesting session for national and international OCGs and Transnational Organized Crime Groups (TOCGs) in Nepal. Since the beginning of the armed conflict in 1996, the competency and efficiency of Nepal Police was irreparably damaged. Before that, Nepal Police was a credible investigating and law enforcement agency. But since the armed conflict after 1996, its mandate, power and authority was curtailed and negotiated by the government and the irregular forces by creating new departments like the Department of Immigration, Department of Money Laundering and the Department of Transport and Licensing Department. These departments, at the present context have become a liability than asst to the government. They have not been fully functional and active to investigate, contain and control organized and financial as they are supposed to do.

At this juncture, former, assertive role of Nepal Police and Armed Police were limited to reactive and more of a protective services that gave full play of serious and organized crimes. The overriding comprehensive power and authority of Nepal Police was disintegrated by the formation of new departments like the department of immigration, department of transport, the department of money laundering and many others. It disintegrated police jurisdiction and mandate on one hand, but it gave 
much more leverage for the OCGs to play around one against the other. The problem with these new departments was their lack of expertise, expertise and strength that was an unmatched to deal with the OCGs. For example, organized crimes, transnational crimes and money laundering demands overriding authority, power and strong law enforcement capability, which these department does not possess.

Similarly, law enforcement of crime and financial investigation is complementary and inseparable. The investigation of money laundering has been assigned to a different set of government servants who have not been able to come with any substantial result in money laundering cases which is the other side of a coin of organized and transnational crime. All these new arrangement gave space to the novo-rich and adventurism that gave way to more gray areas in the society.

Since the beginning of the armed conflict initiated by the Communist Party of Nepal (Maoist) [CPN (M)] Nepal Police started to lose its power and man on the onslaught of the Maoist guerillas. Consequently, Nepal Police became the first victim for it was not prepared for the armed confrontation it had faced during insurgency period. On the other hand, CPM (M) started to behave like an irregular group with all tactics to gain power and money. It gave way to various armed criminal activities like bank robbery, kidnapping, summary execution, extortion to forcible land usurpation. In the year 2006, the Comprehensive Peace Treaty (CPA-2006) recognized the People Liberation Army of the CPN (M) and their sister organization Young Communist League, UNMIN took the responsibility to management of the cantonments and reintegrate the Maoist combatants. At this time, Nepalese security apparatuses had more or less role to play by appeasing the rebel group, factional contradicting political parties. This situation somehow gave full opportunity for illegal, criminal national foreign elements to all activities: legal, semi-legal and sometimes even illegal. In a way, it gave way to impunity and lawlessness to a larger extent.

\section{Organized Crime}

What is organized crime and how do the organized criminals look like? This is a common question that is coloured by the films and media stories where most of the criminal bosses and king pin become the role model for an ambitious risk taking young Nepali who may see and admire them as a hero "sitting behind marble desks, wearing expensive suits, with their ties done up to 11 o' clock". But, they tend to forget that, their role model, wearing expensive suit with their ties done up to 11 o'clock may be a syndicate leader, and boss of the organized syndicate, who may ... steal their cash (Crowley, 2009)!

Some of the crucial features of organized crime are fear, intimidation, and violence. Their prime motive focuses merely on to gain power, earn money, and demand respect by conspiracy, coercion, and corruption, or whatever means. OCGs love to take unwarranted risk, financial misrepresentation, money laundering, engage in white collar crime and fraudulent acts. Comparatively, there might be less violence in organized crime in Nepal compared to Mexico, Colombia, and Afghanistan; because the stage of OCGs in Nepal is still in its infantile stage. It is a common fact that the objective of all criminals whether organized or less organized, white collar or blue collar, one the major motivating factor is money and profit. It is also true that crime of any type will have a lot to do with illegal, unethical and nefarious activities that is prohibited by law.

\section{Some Cases Amounting to Organized Crime in Nepal}

In the fiscal year 2016/17, the government of Nepal spent Rs. 204 billion in capital expenditure in infrastructure projects, out of which it paid its 10 percent (about 20 billion) in bribes and commissions to civil servants, engineers, department heads, secretaries and ministers (Pangeni, 2017). A former president of the Federation of Contractors' Association confesses that, "percent is an open secret and practiced in almost all public procurements. In this regard, spokesperson of the Ministry of Procurement and IT says "the commission are not to be reflected on paperwork and cannot be talked about." that means that engineers of roads and bridges receive Rs. 2.5 million and Rs. 15 million from a contract worth 500 million. These commissions are shared by an entire system ranging from the junior staffers to officers (60 percent) to ministers (40 percent); and those unable to satisfy ministers and politicians get transferred. In these transactions; 'top brass and political parties themselves collect commissions if the contract is too big, worth billions of rupees'. Despite police warning, such corrupt and ill gotten money get distributed onto gang leaders and ringleaders who get around 2 percent, Treasury Controller Office seek up to 0.2 percent, and Auditor's Office also gets 0.2 percent. 


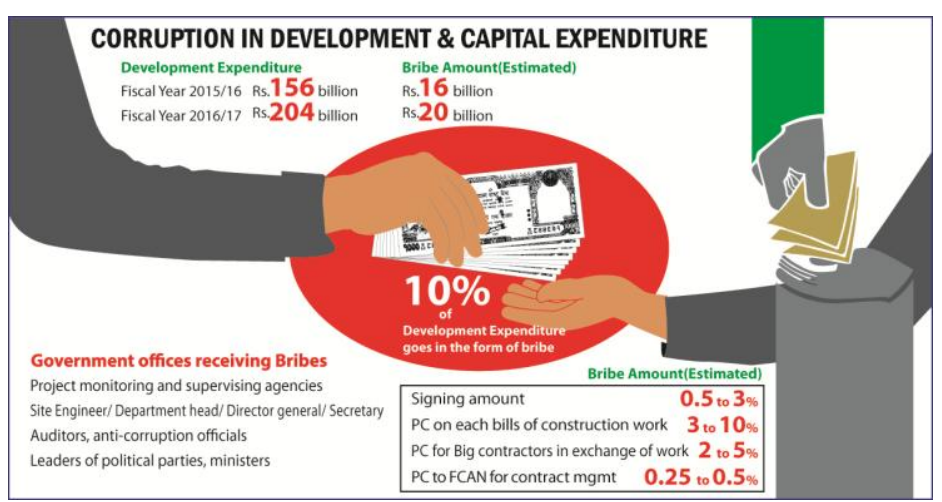

The definition understanding and interpretation of organized crime is different and difficult to understand in Nepal. For example, production, sales and distribution of substandard drugs is as illegal and criminal as selling illegal substances like Hashish, Heroin and Precursor-chemicals that is used to manufacture illegal drugs anywhere in the world.

Source: https://myrepublica.nagariknetwork.com/news/33171/

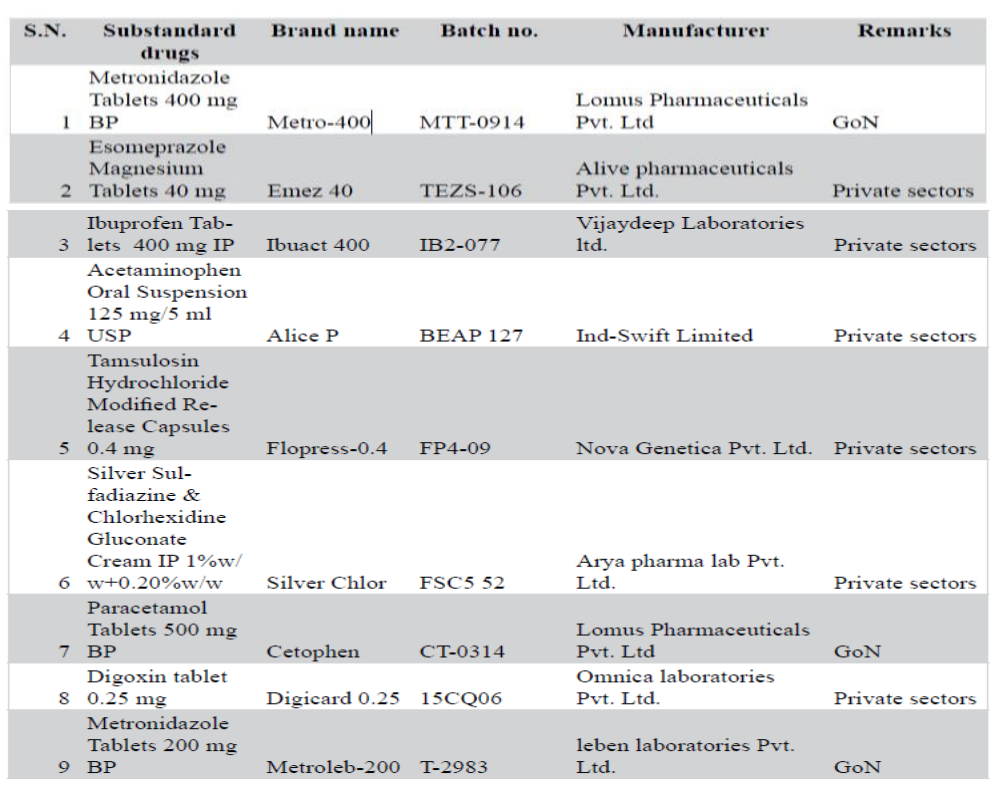

For example, if we look at the list of substandard drugs as given on the left, the responsible department, distributor and the seller of the product need to be prosecuted and penalized immediately. They ought to be treated like the traffickers of narcotic drugs and be prosecuted as severely as any perpetrator of the traffickers of hashish and marijuana. But the public, accountable stakeholders and the government have turned a blind eye because there is a lot of money in this systemic organized crime and corruption. It is a paradox that all responsible parties are mum in such a serious case putting 3 million Nepali lives into a risk.

Source: https://www.inheadline.com/news/nhrc-investigates-substandard-drugs-supplied-by-governmentand-public-sectors

\begin{tabular}{|c|c|c|c|c|}
\hline NAME & AUDITED AMOUNT & UNACCOUNTED & PERCENT & EMBEZZLLED \\
\hline Province 2 & Rs26.58 Billion & Rs 3.53 Billion & $13.27 \%$ & - \\
\hline Province 3 & Not available & Not available & $11.19 \%$ & - \\
\hline 278 Local Units & Not available & Rs 228.1 Million & Not available & - \\
\hline $\begin{array}{l}\text { Khandbari Municipality document } \\
\text { shows Rs } 21.64 \text { Million deposited } \\
\text { in bank }\end{array}$ & $\begin{array}{l}\text { Rs } 13.99 \text { Million } \\
\text { deposited in bank. }\end{array}$ & $\begin{array}{l}\text { Rs } 7.65 \text { Million not } \\
\text { deposited in bank }\end{array}$ & - & - \\
\hline \multicolumn{4}{|c|}{ Pokhara Village Development Committee (VDC) Secretary misused social security fund. } & Rs 3.84 Million \\
\hline \multicolumn{4}{|c|}{$\begin{array}{l}\text { Jijodamandau VDC Secretary misused social security, recurrent and capital budget and reserve fund from } \\
\text { previous fiscal year. }\end{array}$} & Rs 3 Million \\
\hline \multicolumn{4}{|c|}{$\begin{array}{l}\text { Amount financed by } 567 \text { co-operatives and invested by Youth and Small Entrepreneur Self Employment Fund } \\
\text { at high risk. }\end{array}$} & Rs 361.8 Million \\
\hline
\end{tabular}

Source: http://kathmandupost.ekantipur.com/news/2018-04-13/ag-exposes-dubious-accountingpractices.html

Another case of OCGs partnership with the internal agency, the constitutional body and the government of Nepal is demonstrated by the $55^{\text {th }}$ Attorney's Annual Report as given in the table. For example, if we look at the table, the annual report of the Attorney General Office of the Government of Nepal shows that the dubious accounting practices and amount embezzled by corrupt government officials at various levels of local units of the provinces. It is also a form of organized crime in partnership with the government constitutional body, government ministry, semi-governmental agency and the private party. These cases are as serious as any organized crime where guns and physical violence is used. This is a particular example of government, systemic organized crime of the government official in collaboration with the private party. 
Another example of the crime committed by public office in collaboration with the international donors and private parties is well evidenced by the expenditure of millions of dollars by the Election Commission of Nepal (EC). The audit report prepared by the Office of the Auditor General and submitted to the President of Nepal where EC had spent millions of rupees from foreign donors without any audit details (EC spends millions, 2018). Election logistics gifted by Indian and China were not taken into account in its report submitted to the OAG even after holding 3 elections.

It further explains that that the Election Commission (EC) had received 280.90 million from UNDP, Rs. 290.95 from USAID, and Technical Assistance from IDEA. But the EC Body did neither bothered to submit financial details nor asked for the OAG's or auditors' assistance. In this case the EC was also accused of 'promoting nepotism in awarding contracts for voter education programs and producing logistic'. It is said that the EC had also provided 121 percent of salary as additional allownace to election officers during the elections. Apart from not keeping records of foreitn aid and maintaining financial discipline the EC had not settled Rs. 190.71 million arrear ("EC spent Millions in Dollar Funds with no Audit: OAG Report, 2018, Apr 13)”.

One of the living example of the decade long organized crime nexus is the gold smuggling in a low income post-conflict country Nepal. On May, 2018, the violent killing of a gold courrier, Sanam Sakya dramatized the decade old long gold smuggling via Nepal which is guessed to be amounted to 7 tons of gold till the date this case was busted. As for the defence of the gold smuggling there were public outcry to justify the smuggling that advicated the disbalance between the demand and supply of the gold necessiated the smuggling of gold in Nepal. Such alibai and apathy of the government has govenm enough ground for the organized criminal nexus to run the business for decades in Nepal.

According to Raju Chaudhari, $85 \%$ of gold is imported out of Banking process as directed by the Government of Nepal. There is an association of Gold and Silver business houses that challenges that there has never been an investigation and indictment of any gold business persons, therefore, government has no authority to declare such transaction illegal. It shows the gap in the investigation, mandated authrorty for investigation and a clarity in substantive and procedural law regarding gold transation in Nepal. As a result, despite a big hue and cry, the investigatigation of the $33 \mathrm{Kg}$. of gold and prosecutin of offenders have come to nothing till date.

\section{Corruption}

In general terms, corruption can be understood as a transaction propagated by people having influence and vested interest. Generally, corruption is willful conduct or intent aimed at securing undeserving or illegitimate gains through illegal, unethical or immoral means. Characterized by deliberate abuse or misuse of one's authority or position.

According to the 2018 Corruption Perception Index reported by the Transparency International (TI), Transparency International (TI) has ranked Nepal 124 out of 175 countries in their list of least corrupt countries the world. According to the same Report, corruption rank in Nepal has averaged 127.40 from 2004 until 2018. (Transparency International Report, 2019).

Nepal has been gradually losing public trust in its financial system, its politicians and political parties. Politicians in power and their coteries are among the leading perpetrators of corrupt practices. Nepal needs to develop measures to prevent politicization of students, teachers, educational institutions and the civil service as well.

Nepalese government is abusing state funds by arbitrary channelling financial aid to handpicked dubious recipients without any regard for accountability. Such malpractice has inflicted avoidable suffering of the country and the people. As the ultimate accountable entity, the government leadership's deliberate inaction or reluctance to eradicate this evil is equivalent to becoming a partner in crime, and promoting and perpetuating corruption. World Happiness Report 2018 has ranked Nepal 101 among 156 countries of the world. Therefore, Nepal's political leadership has the moral obligation and legitimate 3 authority to end this anomaly (Wostey, 2018). The article cited above clearly illustrates the undesirable, unethical partnership or the organized criminals, brokers, commission agents and the politicization of crime that has introduced a common parlance of "the criminalization of politics and the politicization of crime".

Recently, the government had decided to regulate the Transport Syndicates which it had created to support its own political system. But unfortunately, the government had to withdraw its decision when it 
found out that the transport syndicates had developed onto an organized cartel not weaker than the government by any means. As the issue surfaced into public notice, people were shocked to know that all the public transports were dictated and monopolized by five big syndicates all over the country. For example Prithvi Rajmarg (Highway) Bus Syndicate alone controlled 1,375 vehicles. This Syndicate spends more than 30 million from its welfare fund only. It spends 50 million insurance per year. It has got 400 staffs and 700 driving staffs only. Similarly, area-wise ArnikoYatayat (Arniko Transport) covers four districts and spends 40 million per annum, it has 200 busses and has a total of single and corporate shares of 650 transport agencies. It shows that the private organization like transport organizations, whose partnership and collaboration has become indispensible for the smooth running of the government. There are numerous professional organizations working like a sister and partner organization of various political parties today, such as medical associations, bar association to barber's association and syndicates.

At the present moment, there are five powerful transport syndicates that control the whole of the national transport busineses and they are: Narayani Transport Management Syndicate ( Narayani Yatayat Byabasai Sangathan), West-Nepal Bus Business Organization, Butwal Nepal ( Paschim Nepal Bus Byabasai Sangh), Prithvi Highway Bus Management Syndicate (Prithvi Rajmarga Bus Sanchalak Samiti, Pokhara), Arniko Transport Services Committee, Kathmandu (Arniko Yatayat Sewa Samiti), and Rapti Zone Private Bus Business Committee (Rapti Anchal Sarbajanik Bus Byabasai Samiti).

It shows that the organized syndicates are gaining strength to bargain and on the line to become business cartels if not the organized criminal syndicates as yet. But there is one thing is common in the syndicates, trade unions students and sports associations, i.e. they are developing the characteristics of criminal syndicates and cartels that can be seen in other parts of the world. There are similar features of all these groups with that of the criminal syndicate is that - they all are strongly motivated to make profit, they all are very aggressive and assertive to protect their interest, they have their own code of reward and punishment, protection of their own interest; and ultimately they are becoming more powerful and united to challenge the government to assert their interest before the national welfare an interest. There are many instances where the government and its constitutional bodies show helplessness to take action on the bureaucratic highhandedness and abuse.

The broad definition put forward by the UN Convention against Transnational Organized Crime, where OCGs are described as:

a structured group of three or more persons, existing for a period of time and acting in concert with the aim of committing one or more serious crimes or offences in order to obtain financial or other material benefit (UNODC, 2010).

How to translate this definition in Nepali parlance? In practice, organized crime is about making money as much as possible as quickly as possible through any means available, both legitimate and illicit. That is exactly what is happening in the social, political and economic of post conflict Nepal after the Comprehensive Peace Agreement of 2006. Like any other countries of the world, public perception of Nepalese is also often influenced by the glamorized portrayal of organized crime in fictional representations in television and film, as opposed to the less sophisticated groupings of "seedy, immoral, and grubby individuals" who make up a typical OCG. This mismatch between reality and perception equally applies to the methods and resources available to tackle the threat, and subconsciously influences expectations at every level (Keene, 2018, p. 8).

\section{Challenges of Organized Crime in Nepal}

For most of the $20^{\text {th }}$ century, organized crime was predominantly seen as a law enforcement problem. However, this changed during the 1990s when organized crime, especially transnational organized crime (TOC), evolved to become a wide-ranging security issue as a consequence of globalization and market deregulation (Williams, 2009). Organized crime is not a new phenomenon in Nepal, but contemporary socio-political mindset of globalization, democratic freedom and changed social political context seems to have embraced it to a very dangerous proportion.

Besides political, socio-economic reasons, they are other factors that have contributed speedy momentum and energy to OCGs and TOCs in Nepal. "As Internet and cell phone technologies became increasingly accessible and affordable, they also inadvertently supported the activities of global criminal networks. Consequently, OCGs flourished, taking advantage of all the technological, physical, and economic 
advantages globalization had to offer, enabling them to expand geographically across borders to become better networked and interconnected than ever before (Keene, 2018, p. 4).

In the year 2000, United Nations (UN) Convention against Transnational Organized Crime represented a milestone in global policy response to the threat. Warnings about the rise of organized crime also came from several additional sources including the UN Office of Drugs and Crime (UNODC, 2010). Concurrently, the complex nature of organized crime and its threats have been heavily talked and debated in Nepal too. But the lack of adequate understanding, seriousness and commitment from the government and the people has given full advantages to the OCG and TOC locally, vertically and horizontally. Talking about locally, Nepalese people understand and know goons like , Chakre Milan, Min Krishna Maharjan, Dinesh Adhikari aka Chari, Gaite, Deepak Manage, Ganesh Lama and so many in the capital of Nepal. There are several such notorious law breakers, goons, government contractors and brokers who are exposed but proven untouchables by the concerned stakeholders; whether it is the government, public or private entity. Vertically there are many people in the government, politics, bureaucracy; people roaming around their periphery who get exposed repeatedly with no indictment, action, prosecution. Time and again, big names of Nepalese business tycoons and social political stalwarts and their suspected involvement in the capital flight and money laundering, tax evasion and international scams, stashing billions of dollars in Panama, Switzerland and many off-shore banks.

In Nepal, like any other countries of the world, 'there is a tendency of oversimplification and generalizations in describing and tackling organized crime has been observed widely by scholars and practitioners' (Keene, 2018, p.9). In the case of fragile states in particular, there is a further tendency to use the term "OCGs" or "TOC" to describe all types of organized crime activity, as well as seeing TOC as an inevitable consequence of the fragile environment without understanding the dynamics of how and why they occurs (Keene, 2018, p. 9). This may be one of the reasons, why Nepalese government to responsible law enforcement officers to the people in general take organized and transnational crime as a normal destiny to be taken too lightly as if it is nothing.

\section{Transnational Crime}

OECD defines Transnational Organized Crime as:

"Transnational organized crime (TOC) has recently developed in ways that place it at the top of the international agenda. Advances in technology and communications as well as in the global political economy have brought about significant changes in the way TOC behaves and operates. TOC is established in many countries around the world irrespective of their levels of development. It is a fluid and diversified industry that engages in a host of illicit activities including drug trafficking, human trafficking, piracy and counterfeiting. Although it may affect strong states, it is above all conflict affected or otherwise weakened states that are vulnerable to TOC predations and may serve as bases for international criminal enterprises (Miraglia \& Briscoe, 2012)."

Most widely-accepted definitions however presents two important elements when defining TOC: 1) sales of illegal goods and services; 2) a certain organized structure with some form of hierarchy that has its goal the profiting from the above mentioned provisions of goods and services; and 3) the perpetuation of their existence through violence (or threat of violence) and corrupt relations with public officials (Miraglia \& Briscoe, 2012). With secrecy being one of the foundations of TOC's survival it is difficult to assess the scope of its diversity and operations; however today we do know much more about TOC than ever before. But the problem with the TOC is the lack of adequate understanding of the term. However, (OECD) elucidates TOC as follows:

With secrecy being one of the foundations of TOC's survival it is difficult to assess the scope of its diversity and operations; however today we do know much more about TOC than before. The sweeping generalizations which are often used to bracket together international crime and fragile states as a leading global 'threat' tend to ignore important nuances in the way particular countries and regions have been incorporated into illicit markets (Miraglia \& Briscoe, 2012).

\section{State Failure and Organized Crime}

US Fund for Peace and Foreign Policy magazine have identified 12 indicators of state failure that is further sub-divided into social, economic and six political indicators. It has pointed demographic pressure, refugees or internally displaced people, vengeance and ethnic grievances / violence, and human flight as social indicators. It has identified - uneven economic development and economic decline, balance of payment, inflation, unemployment and capital flights as economic indicators. And, most importantly, it has identified six political indicators as - the criminalization of politics, (politicization of 
12 INDICATORS OF FRAGILE STATE - INDEX 2018

\section{COHESION INDICATOR \\ ECONOMICINDICATOR}

\section{POLITICAL INDICATOR}

SOCIAL INDICATOR

CROSS CUTTING IDICATOR
C. 1. Security Apparatus

C. 2. Factional Elite

C. 3. Group Grievances

E. 1. Economic Decline / Poverty

E. 2. Uneven Development

E. 3. Human Flights / Brain Drain

P. 1. State Legitimacy

P. 2. Public Service

P. 3. Human Rights \& Rule of Law

S. 1. Eemographic Pressure

S.2. Refugee and IDPs

E. 1. External intervention

Source : https://issuu.com/fundforpeace/

docs/951171705_fragile_states_index_annu

crime), endemic corruption and lack of transparency and accountability, and loss of people's confidence on state institutions, deterioration of public services, politically induced violence, abuse of legal and political rights; abuse of security institution as "state within a state", factions and fragmentation among ruling elites and state institutions, and growing foreign interest, influence and political indicators leading to a failed state (Fund For Peace, 2018). Although, Nepal has got a two third majority government and the government is striving for rapid economic development, but the indicators are showing quite the opposite. All these have to be studied on the basis of local, national, serious organized and including transnational crime indicators, corruption, money laundering and capital flight, brain drain.

According to Fragile State Index 2018, Nepal has fared Afghanistan $9^{\text {th }}$ Position with 107.3 points, Pakistan (17 ${ }^{\text {th }}$ Position with 98.9 point), Nepal in the 33 position with 91.0 , point, Bangladesh $39^{\text {th }}$ Position with 89.1 Point, Sri-Lanka $-47^{\text {th }}$ Position with 86.6 Point, India - $72^{\text {nd }}$ Position with 77.9 Point, and Bhutan with $83^{\text {rd }}$ Position 76.0 Point, Maldives in the $86^{\text {th }}$ Position with 74.4 Points (The Fund for Peace, 2018).

\section{Models of Organized Crime}

OECD has also classified different types or models of organized crimes as follows:

- Local organizations primarily concerned with local crime;

- Local organizations with global reach (illicit production)

- Transnational logistical networks and

- Fragile states as transit points for transnational organized crime

\section{Local organizations primarily concerned with local crime:}

Local crime may occur and become exacerbated as a result of the absence of a functioning state or inclusion with the state. Examples have been observed in post-conflict countries where OCG have been involved in significant criminal activities with strong state links. However, their linkage with transnational illicit markets carry marginal importance which may be sporadic than systematic. In tackling localized crime, a localized disruption strategy utilizing local actors may be sufficiently enough. In such a situation, adequate consideration and response need to be prioritized so that it does not aggravate the people so they may come to street to challenge the government institution as a whole. The police encounter of Dinesh Adhikari aka "Chari" to Ghaite, Ganesh Lama, Chakre Milan, Gorkhali and various Don scattered around the country may be classified under this category. This also shows the risk of police high-handedness of orchestrating fake encounters that may lead to more revenge killing and gun culture and violence as seen in Mexico and Afghanistan and Sudan and so many other post conflict countries.

\section{Local organizations with global reach (illicit production):}

In comparison to the locally confined crimes, more efforts and international approach may require to address and tackle local organizations with global reach. Recently many great events have been exposed by Nepalese media where Nepalese local parties with global reach have been questioned by the public at least. The exposures of seven business houses with direct link with PANAMA PAPERS, 52 business houses with their undeclared foreign bank accounts abroad and purchase of aboard to Wide Body Aircraft has been the latest episode where the suspected persons are Nepalese with international connections.

Such parties can be described as having TOC origin at home and their unspecified questionable involvement abroad. Some of the examples are, cultivating and producer nation of any narcotic substance or illicit goods manufactured in conditions of conflict and distributed to the global market through 
international commercial intermediaries. The key factor that determines these types of organized crime groups is their supply chain requires logistical skills in transport and delivery, as well as domestic and international connection to succeed. A recent case of precursor chemical, Pseudo-ephedrine was seized where the owner of big pharmaceutical company and also the founder of the prestigious bank was arrested and indicted. Sanghai who owned a pharmaceutical company who was also the founder of Sunrise Bank was arrested by the Narcotic Control Bureau of Nepal. The chemical he used to trade via Nepal was neither produced in Nepal not used to produce the any medicine. But despite all hue and cries, the case got cooled down with any further investigation without any legal action and prosecution. The notorious case of $33 \mathrm{KR}$. Gold Smuggling can be taken as an example of such case.

The key factor that determines the success of this type of OCG is it illicit supply chain which requires logistical skills in transport and delivery, as well as domestic and international connections to succeed. Here, domestic and international interventions combined would seem most appropriate to disrupt the criminal network both in-country and internationally.

\section{Transnational logistical networks:}

The significance of the third category identified, namely transnational logistic networks, is that they play central role as intermediaries in the global distribution of illicit goods. Although as much as $85 \%$ of the total value of trade is estimated to derive from the drug trade according to the UNODC, established illicit networks can also be utilized for other criminal commodities (UNODC 2010).

\section{Fragile states as transit points for transnational organized crime:}

The fourth and final category identified by OECD is nation-states, which allows countries to become safe havens for global, local, and international crime. This is highly relevant as the state, which is supposed to disrupt crime, is instead a sponsor and an enabler of crime; ... in which corruption plays the key (Keene, 2018, p.11).

\section{Traditional Organized Crime and Its Deviation}

Since last two decades, there has been a significant change in OCG and TOC activities. Contemporary OCGs have moved away from a system of hierarchical, turf-based groups into interconnected, flexible, and opportunistic networks. Unlike traditional OCGs like Mafias, Yakuja, Tirade and Korean and Vietnamese, new types of OCGs have new formations comprising broader, developed, and less formal structures, often lacking formally defined roles or its members, where continuity of membership is often less of a defining factor (Reed 2009, p. 8).

Another recent change that has been observed in many countries is the move away from a monopolistic setting where one or two larger criminal organizations control international criminal trade, to the emergence of smaller, more reactive networks. This flatter, more informal structure has come about partly as a result of advancements in communications technology which enquire less formalized command and control structures to be in place (Shawand \& Kemp, 2012, p. 7).

As a result, these less formal structures can make it difficult for intelligence analysts, law enforcement agencies to conduct up-to-date network analysis and operations as their relationship and membership constantly keep on changing (Keene, 2018, p.12).

\section{Negative Impact of Organized and Transnational Crime}

- OCG activities can be harmful to stabilization, peace-building, and development of a country in several ways. For example, criminal funds may distort the political process by funding the activities of some political parties and not others. This in turn may result in corrupt parties getting into power or retaining the power.

- Another destabilizing factor of widespread OCG' presence is its impact on the local economy. When legitimate means of economic survival gets threatened by OCG activities, it leads to economic instability, inflation, unhealthy competition, corruption that may lead to further increase in crime when legitimate means of economic survival becomes difficult if not impossible and ultimately further conflict and violence (Keene, 2018, p. 13).

- In a fragile economy of a post conflict political transition, it is natural for government and people to strive hard to strengthen local economy. When organized group undermine healthy economic growth through syndicate, partisan politics; through immoral illegal practices corruption, 
intimidation and violence, it will drive the society into organized crime and violence. Such environment is likely to prevent new businesses from opening, thus reducing the legitimate employment opportunities as well as fair trade and market competition.

- A poor economic environment will also result in brain drain and muscle drain; as well as scaring away foreign investors and donors to divert their investment elsewhere; (Keene, 2018, p. 14). Because, without a vibrant economy there is no place to invest or spend the money. When this phenomenon is ignored by the government and the OCG, the economic health of the country is doomed to failure.

- Suppose, even where criminal money is injected or stays in the country, there will be a lot of negative consequences which affect the local economy and have a destabilizing influence in the country. One example is price inflation, which can occur as a result of the circulation of criminal money. This in turn increases the cost of living and makes their people struggle just to survive or become poorer or dependent more on foreign aid. In such situations where aid is unavailable, or where regular aid is withdrawn by the donor, the recipient country will be forced to resort to crime as the only means of their survival. This will automatically induce petty criminals to join organized crime and develop themselves of new OCGs from among themselves. Transport Syndicate and Trade Unions resembles this group in a larger extent. Many poor conflict ridden countries of Africa and Asia like Afghanistan, Sudan, Sierra Leon and CIS countries and countries of former Yugoslavia and even Nepal may be put into this category. Whenever such countries resort to crime, joining OCG or insurgency group in return for payment or sustenance, further strengthening the position of these groups (Shawand \& Kemp, 2012).

\section{Irregular Forces}

IHL refer the term 'irregular forces' to combatants that form part of a country's armed forces in an armed conflict and that do not belong to country's regular forces (Boczek, 2005). CPN (Maoist) prior to 2006 Comprehensive Peace Agreement could be termed as Irregular Force of Nepal.

On the other hand, to be categorized as 'regular armed forces," the Hague Conventions' $(1899,1907$, and Hague IV) four conditions must be met. First, they are commanded by a person responsible for his subordinates to a party of conflict. Second, regular forces have a fixed distinctive emblem, recognizable at a distance. Third, they carry arms openly, and fourth, they conduct operations in accordance with the laws and customs of war (The Geneva Convention 1949). Combat forces that do not satisfy these criteria are referred to as irregular forces. As such insurgency groups and terrorist organizations fall under the definition of irregular groups (Keene, 2018, p.16). The fundamental difference between OCGs and irregular groups may differ in motivation and aspirations. The OCGs are found to be driven predominantly by economic gain and power; whereas irregular groups may be seen as being more motivated by political change. But in many ways, drivers of OCGs may look similar to private organizations whose aim is also to maximize profit. All OCGs are essentially a business, albeit criminals generally intend to enjoy the illegal proceeds through legitimate way or use legal proceed in illegitimate business whereas irregular groups may be more willing to die fighting for their cause (Keene, 2018, p. $15)$.

The primary motivation for terrorism and irregular groups in general, however, may not be only financial. For them finance is a means to an end, that may be either ideological and political aspirations or financial gain for power and prestige ("Money laundering \& Terrorist Financing - A Global Threat, 2004)". A significant portion of terrorist funding is derived from donors, some of them may be fully aware of the intended purpose of their contribution and others may not be (Keene, 2018, p. 17). Nonetheless, where legitimate resources of funding such as donations are inadequate or unavailable, terrorists also may seek alternative sources by turning to criminal activity, such as extortion and hostage taking for ransom. Like any criminal network, terrorist organization may also derive funding from a variety of criminal activities of varying scale and sophistication form low level crime to serious organized crime ("Money laundering \& Terrorist Financing - A Global Threat, 2004").

In some cases, terrorist's involvement in trafficking and crime may not be only strategic; they may do it for sustaining their organization financially. They may also garner and provide them political support and legitimacy within and among local population which depend upon the protection and for their livelihood. Such criminal activity is rife in fragile sates where the risk of prosecution is low as a consequence of weak or absent rule of law (Keene, 2018, p. 19). 
More often both OCGs and the irregular forces demonstrate the ability to move between licit and illicit markets to finance their activities, particularly by laundering money. Traditionally, money laundering is associated with the proceeds of crime, which is usually derived from the sale and distribution of illicit goods and services, which is then moved in a way so as to disguise its origin and appear as legitimate funds. Money laundering techniques are used not only to conceal money origination from narcotics, but also for a whole range of other criminal activities (Keene, 2018, p. 20).

\section{Organized Crime and Irregular Groups}

There are scholars and practitioners who acknowledge that there is always a possibility for OCGs and irregular group (that may include terrorist organizations) to convergence through collaboration, alliances and tactical appropriation, reaching some central point where their objectives meet. Others argue that their partnership may even go beyond convergence to emerge into hybrid groups, which share common ground in ideology, modus operandi, and profit generation.

\section{Transnational Organized Crime and Fragile States}

\section{Hybrid Entities}

The hybrid entities concept builds on the theory of convergence, whereby the entities continually converge to the point where the two groups actually become one hybrid group. According to the report for the European Parliament in 2012:

Hybrid groups either begin as organized crime groups that appropriate terror tactics and simultaneously seek to secure political aims, or they begin as terrorist groups that appropriate criminal capabilities to the point that they begin to use their political (ideological) rhetoric as a façade for perpetrating organized crime (Keene, 2018).

\section{TOC and Security Organizations in Nepal}

Politicians in Nepal also have vocalized TOCs and OCGs as their top priority and policy, which then filter down to security institutions such as Nepal Police and Armed Police Force, Nepal. To actualize this commitment, politicians need to be able to demonstrate their seriousness in action. But there is a great risk that dealing with the OCGs and TOCs on ad-hoc basis and its gross generalization can be very counterproductive and harmful to the society and the nation as a whole (Keene, 2018, p. 8).

\section{Conclusion}

The fundamental questions for all concerned stakeholders of Nepal have a minimum level of conceptual, metaphysical, methodological understanding of organized crime, transnational crime and white collar crimes? It is also necessary to examine the seriousness, committed of the government to deter, prevent, deter, or obliterate (if possible) the cause and consequences of the organized crime? Because it is far elusive, complicated, difficult, risky than dealing with day to day isolated, petty, emotionally led street crimes. Below listed concluding recommendation can be applicable:

- Recognize OCGs as a threat to the National Security

- Widen the scope of network analysis - enhance intelligence assessment by widening the network

- Tackle corruption - develop and understanding of how corruption enables partnership to from between OCGs irregular groups, state officials, and identify ways in which this can be tackled.

- Address intelligence knowledge gaps - develop multidisciplinary approach incorporating experts from different disciplines.

- Provide training and education to enable deeper understanding of how OCGs, irregular groups, and corrupt state officials collaborate. Adopt an integrated approach to ensure that the widest possible intelligence picture is captured on OCGs and state actors, and engage dialogue to develop a collaborative approach to tackling the problem

- Prepare for unintended consequences and consider how these can be mitigated.

\section{References}

Adhikari, S. (2012).Chakrabiumachandrasurya. Sangi-La publications.

Boczek, B. A. (2005).International Law: a Dictionary.MD: Scarecrow Press. 
Crowley, J. (2009). 10 biggest white-collar crimes in history (and how they were unraveled). Business Pundit. Retrieved from http://www.businesspundit.com/white-collar-crimes-history-and-how-they-wereunravelled/

EC spent millions in donor funds with no audit: OAG report. (2018). My Republica. Retrieved from https://myrepublica.nagariknetwork.com/news/ec-spent-millions-in-donor-funds-with-no-audit-oagreport/

Felbab-Brown, V. (2013). The Impact of organized crime on Governance: A case study of Nepal. Brookings. Retrieved from https://www.brookings.edu/articles/the-impact-of-organized-crime-on-governance-acase-study-of-nepal/

Kharel, A. K. (2018). Achyut Krishna Kharel's autobiography. Nepalaya Publication.

Keene, S. D. (2018). Silent partners: Organized crime, irregular groups, and nation-states. Army War College (U.S.). Retrieved from http://ssi.armywarcollege.edu/pubs/download.cfm?q=1392

Miraglia, P., Ochoa, R., \&Briscoe, I. (2012). Transnational organized groups and fragile states. OECD Development Cooperation working papers, International Center for the Prevention of Crime and the Clingendael Institute, Retrieved from https://www.oecd.org/dac/accountable-effectiveinstitutions/WP3\%20Transnational\%20organised\%20crime.pdf

"Money Laundering and Terrorist Financing - A Global Threat," (2004). International Narcotics Control Strategy Report ,Washington D.C.: U.S. Department of State, Retrieved from, https://www.state.gov/j/inl/rls/nrcrpt/2003/vol2/html/29843.htm

Reed, Q. (2009). Squeezing a Balloon? Challenging the Nexus between Organized Crime and Corruption, 7(4). p.8

Rudra, P. (2017, December 25). Contractors, suppliers paid Rs 20 billion in bribes last year. My Republica.

Shawand, M \& Kemp, W. (2012). Spotting the Spoilers: A Guide to Analyzing Organized Crime in Fragile States. New York: International Peace Institute.

Sushila, K. (2018). (Nyaya) Nepali .Hill Publication Nepal.

Taylor, G (1962), Organized Crime in America. The University of Michigan Press, pp . 85

The Fund for Peace. (2018). Fragile states index annual report 2018. Retrieved from https://issuu.com/fundforpeace/docs/951181805-fragile-states-index-annu

The Geneva Convention III (1949)

UNODC. (2000). United Nations Convention against Transnational Organized Crime and the Protocols Thereto. Retrieved from https://www.unodc.org/unodc/en/organized-crime/intro/UNTOC.html

UNODC. (2010). The Globalization of Crime : A Transnational Organized Crime Threat Assessment. Vienna.

Williams, P. (2009). Criminals, Militias, and Insurgents: Organized Crime in Iraq. Strategic Studies Institute: U.S. Army War College.

Wostey, S. (2018). Catch the corrupt. Retrieved from http://kathmandupost.ekantipur.com/news/2018-0408/catch-the-corrupt.html 